\title{
Quality characteristics of Rehmannia glutinosa dried at different drying temperature
}

\author{
Yae Jin Kim, Kyung Ho Ma, Jong Won Han, Sang Hoon Lee, \\ Jae Ki Chang, Sin Hee Han* \\ Department of Herbal Crop Research, NIHHS, RDA, Eumseong 27709, Korea
}

\section{건조 온도에 따른 지황의 품질 특성 \\ 김예진 · 마경호 · 한종원 · 이상훈 - 장재기 · 한신희* \\ 농촌진흥청 국립원예특작과학원 인삼특작부}

\begin{abstract}
Rehmannia glutinosa (RG) is a widely cultivated medicinal crop in Korea. Its rhizomes are commonly distributed in dried form as a food or traditional medicine. However, very little research into the drying methods for $R$. glutinosa has been conducted. This study was performed to determine the effect of the drying temperature on the quality characteristics of $\boldsymbol{R}$. glutinosa. The famous domestic cultivar 'Dagang' was used for the study. The drying experiments were carried out at $40,50,60,70$, and $80^{\circ} \mathrm{C}$ in a hot air dryer. All samples were dried until their moisture content was less than 12\%; the moisture content of the raw root was $78.97 \pm 1.27 \%$. Under the hot-air drying conditions, the drying process required $288 \mathrm{~h}$ at $40^{\circ} \mathrm{C}, 144 \mathrm{~h}$ at $50^{\circ} \mathrm{C}, 45 \mathrm{~h}$ at $60^{\circ} \mathrm{C}, 22 \mathrm{~h}$ at $70^{\circ} \mathrm{C}, 12 \mathrm{~h}$ at $80^{\circ} \mathrm{C}$. The physical properties of RG were different for each drying temperature. When the temperature was increased, the lightness color value decreased. Hardness which is an important texture factor, was high for a drying temperature of $50-60^{\circ} \mathrm{C}$ and relatively low for $40^{\circ} \mathrm{C}, 70^{\circ} \mathrm{C}$, and $80^{\circ} \mathrm{C}$. The catalpol content increased with increasing temperature up to $70{ }^{\circ} \mathrm{C}$, and then decreased at higher temperature. Considering the overall characteristics of the dried RG, hot-air drying at $60^{\circ} \mathrm{C}$ is optimal to achieve desirable physical properties and high active content. These results should provide useful information for the manufacture of high-quality dried RG.
\end{abstract}

Key words : Rehmannia glutinosa, drying, quality characteristics, temperature

\section{서 론}

지황(Rehmannia glutinosa)은 국내에서 재배되는 주요 약용작물 중 하나로, 원산지는 중국이며 현삼과에 속하는 다년생 초본이다. 지황의 잎은 긴 타원형으로 주름이 많이 있으며 흰색의 잔털이 밀생해 있다(Park 등, 2002). 지황은 비교적 기후가 온난하고 물 빠짐이 좋은 토양에서 잘 자라 며 국내 주산단지로는 금산, 정읍, 안동 등이 있다.

지황의 뿌리는 원기둥 또는 방추형 모양을 이루고 길이
는 5-15 $\mathrm{cm}$, 지름은 5-15 $\mathrm{mm}$ 이다. 바깥면은 황갈색에서 흑갈색을 띠고 깊은 세로주름과 가로로 곁뿌리의 자국과 껍질눈이 있다. 또한, 특유한 냄새가 있고 맛은 처음에 약간 달고 후에 약간 쓰다(KFDA, 2014).

지황의 주요 효능으로는 항종양(Chao 등, 2006), 면역 증진(Liu 등, 1998), 신경보호(Li 등, 2005), 골다공증 감소 (Oh 등, 2003) 등이 연구된 바 있다. 특히 지황의 iridoid 배당체 중 카탈폴은 치매치료(Jiang 등, 2015), 당뇨병 (Zhou 등, 2015), 신장병(Zhao 등, 2016) 등의 치료에 효과가

*Corresponding author. E-mail : herbman@korea.kr, Phone : +82-10-2508-2786, Fax : +82-43-871-5659

Received 24 October 2019; Revised 21 November 2019; Accepted 21 November 2019.

Copyright (c) The Korean Society of Food Preservation.

This is an Open Access article distributed under the terms of the Creative Commons Attribution Non-Commercial License (http://creativecommons.org/licenses/by-nc/4.0) which permits unrestricted non-commercial use, distribution, and reproduction in any medium, provided the original work is properly cited. 
있으며, 아큐빈은 간보호(Chang, 1998), 항염증과 항산화 (Reina 등, 2013) 등에 효과가 있다고 보고되었다.

노지에서 재배하는 대부분의 약용작물은 주로 가을 이 후에 수확하기 때문에 바로 판매하는 경우도 있지만 시장 수요나 판매가격 등에 따라 단기 또는 장기저장 후 사용되 는 경우가 많은데, 생물 형태로는 장기저장이 어렵기 때문 에 주로 건조한 형태로 저장된다. 이러한 수확 후 과정에서 여러 가지 물리적, 화학적 변화가 발생하는데 특히 건조는 수확 후 첫 가공과정으로, 건조 방법이나 온도 등에 따라 유효성분이나 여러 가지 당류의 함량 변화가 나타날 수 있다. 특히 지황은 용도에 따라 건지황과 숙지황으로도 많이 활용되기 때문에, 수확 후 고품질 건지황을 제조할 수 있는 건조기술 연구가 선행되어야 한다.

관행적으로 지황 재배농가나 업체에서는 수확한 생지 황을 세척하여 음건으로 물기를 제거한 후, 열풍건조기에 서 건조하는 것이 일반적이다. 하지만 건조온도와 시간에 대해서는 표준화하여 정해진 바가 없기 때문에 각자 적절 한 방법을 찾아 건조하고 있으며, 이러한 건조방법의 차이 는 건조된 지황의 품질 차이로 이어진다. 또한, 건지황은 증숙과정을 거쳐 숙지황 제조로도 이용되기 때문에 숙지 황의 품질에도 근본적인 원인이 될 수 있다.

따라서 균일한 품질의 건지황을 제조하기 위해서는 적 절한 건조조건 설정이 매우 중요한데, 아직까지 건조감량 에 대한 기준이나 구체적이고 실용적인 공정이 마련되어 있지 않은 실정이다. 이를 위해 본 연구에서는 지황의 최적 건조조건을 설정하여 산업체나 농가에 균일하고 고품질 의 건지황을 제공할 수 있는 표준화 방법을 제시하고자 한다.

\section{재료 및 방법}

\section{실험재료}

본 실험에 사용된 지황은 ‘다강' 품종으로, 2017년에 충 북 음성 소재의 국립원예특작과학원 인삼특작부 시험포장 에서 수확하였다. 수확 후 오염물을 제거하여 충분히 세척 한 후, $10 \pm 1.0 \mathrm{~mm}$ 굵기의 지황을 선별하여 사용하였다.

\section{건조 조건}

건조는 열풍건조기(UDS-2511F, KyungDong Navien Co., Ansan, Korea)를 이용하여 진행하였으며, 온도조건은 5 조건 $\left(40^{\circ} \mathrm{C}, 50^{\circ} \mathrm{C}, 60^{\circ} \mathrm{C}, 70^{\circ} \mathrm{C}, 80^{\circ} \mathrm{C}\right)$ 으로 설정하였다. 각 온도별로 건조는 수분함량이 약 $12 \%$ 도달할 때까지 진행 하였다.

\section{카탈폴 열처리 조건}

카탈폴 성분의 열에 대한 안정성을 확인해보기 위하여
catalpol(Sigma, Cat. No. 50839) 표준액만을 heating and cooling block(HB-R48, DAIHAN Scientific, Wonju, Korea) 에 $100^{\circ} \mathrm{C}$ 온도로 열처리하여 4 시간 간격으로 함량 변화를 관찰하였다.

\section{수분함량 및 건조소요시간 측정}

수분함량은 $\mathrm{AOAC}$ 방법(AOAC, 1995)에 준하여 상압가 열건조법으로 시료를 3 회 반복하여 측정하였고, 12 시간 간격으로 건조기에서 시료를 꺼내어 수분함량 변화를 조 사하였다. 온도별 건조 소요시간은 수분함량이 $12 \%$ 까지 감소하는 데에 걸리는 시간으로 계산하였다.

\section{색도 측정}

색도는 색차계(CM-2600d, Konica Minolta, Tokyo, Japan)를 이용하였으며, 명도를 나타내는 L값(lightness), 적색도를 나타내는 $\mathrm{a}$ 값(redness), 황색도를 나타내는 $\mathrm{b}$ 값 (yellowness)을 3회 반복 측정하여 평균값으로 나타내었다. 이 때 사용한 표준 백판의 색도는 L-value=99.13, a-value $=0.01, \mathrm{~b}$-value $=-0.14$ 이었다.

\section{경도 측정}

경도는 texture analyzer(TestXpert, Zwick $\mathrm{GmbH} \& \mathrm{Co}$, Ulm, Germany)를 이용하여 texture profile analysis(TPA)를 실시하였다. 시료는 texture analyzer plate 중앙에 편편하게 놓고 시료를 2 번 압착하여 경도를 측정하였으며, 측정조건 은 Table 1 과 같다.

\section{카탈폴 함량 측정}

카탈폴 함량 측정을 위해 동결건조한 시료 $0.5 \mathrm{~g}$ 에 증류 수 $10 \mathrm{~mL}$ 를 가하고 1 시간 초음파 추출한 다음 $13,500 \mathrm{rpm}$ 에서 10 분간 원심분리한 상등액을 $0.45 \mu \mathrm{m}$ syringe filter로 여과하여 분석용 시료로 사용하였다. 분석을 위해 high performance liquid chromatograph(HPLC 1200 series, Agilent Co., Waldborn, Germany)를 사용하였고, 컬럼은 YMC-pack

Table 1. Operation condition for texture profile analysis by texture analyzer

\begin{tabular}{cc}
\hline Parameter & Operation condition \\
\hline Load cell & $25 \mathrm{~kg}$ \\
Pre-test speed & $3.0 \mathrm{~mm} / \mathrm{s}$ \\
Test-speed & $1.0 \mathrm{~mm} / \mathrm{s}$ \\
Post-test speed & $1.0 \mathrm{~mm} / \mathrm{s}$ \\
Distance & $30 \%$ \\
Time & $3 \mathrm{~s}$ \\
\hline
\end{tabular}


ODS-AM(250×4.6 mm, $5 \mu \mathrm{m}$, YMC Co. Ltd., Kyoto, Japan) 으로 분석하였다. 검출기는 ultraviolet diode array detector(UV-DAD, HPLC 1200 series, Agilent Co., Waldborn, Germany)를 사용하였고, 검출 파장은 $210 \mathrm{~nm}$, 컬럼온도는 $30^{\circ} \mathrm{C}$, 주입량은 $10 \mu \mathrm{L}$ 로 설정하였다. 이동상 조건은 $1 \mathrm{~mL} / \mathrm{min}$ 의 유속에서 $\mathrm{ACN}: \mathrm{H}_{2} \mathrm{O}: \mathrm{HCOOH}(3: 97: 0.1)$ isocratic 조건으로 설정하였다.

\section{총 폴리페놀 및 총 플라보노이드 함량 측정}

총 폴리페놀의 함량은 Folin-Denis법(Folin and Denis, 1912)을 변형하여 측정하였다. 시료 추출액 $0.1 \mathrm{~mL}$ 와 증류 수 $0.4 \mathrm{~mL}$ 를 가한 용액에 $1 \mathrm{~N}$ Folin-Ciocalteu's phenol reagent $0.05 \mathrm{~mL}$ 를 첨가 및 혼합한 다음 실온에서 3 분간 반응시킨 후, $\mathrm{Na}_{2} \mathrm{CO}_{3}$ 포화용액 $0.1 \mathrm{~mL}$ 와 증류수 $0.35 \mathrm{~mL}$ 를 첨가하여 실온에서 1 시간 동안 발색시켰다. 발색된 시료는 $15,000 \mathrm{rpm}$ 에 10 분간 원심 분리하여 상등액을 $725 \mathrm{~nm}$ 에서 분광광도계(Multiskan GO Microplate Spectrophotometer, Thermo Scientific, Vantaa, Finland)를 사용하여 측정하였 다. 총 폴리페놀 함량은 catechin을 이용하여 작성한 표준 곡선으로부터 값을 산출하였다.

총 플라보노이드의 함량 측정은 Davis 방법(AOAC, 1995)을 변형하여 시료 $0.1 \mathrm{~mL}$ 에 $90 \%$ diethylene glycol $1 \mathrm{~mL}$ 와 $1 \mathrm{~N} \mathrm{NaOH} 0.1 \mathrm{~mL}$ 를 가하여 $37^{\circ} \mathrm{C}$ 수조에서 1 시간 반응시킨 후 $420 \mathrm{~nm}$ 에서 흡광도를 측정하였다. 총 플라보 노이드 함량은 naringin을 이용하여 작성한 표준곡선으로 부터 값을 산출하였다.

\section{항산화 활성}

DPPH radical 소거능은 Han 등(2019)의 방법을 변형하 여 $0.2 \mathrm{mM} \mathrm{DPPH}$ 메탄올 용액 $160 \mu \mathrm{L}$ 에 추출물 $40 \mu \mathrm{L}$ 를 가한 후, $23^{\circ} \mathrm{C}$ 암실에서 30 분간 반응시킨 후 $517 \mathrm{~nm}$ 에서 흡광도를 측정하였고, 대조구로 L-ascorbic acid를 이용하 였다. 총 항산화력은 L-ascorbic acid에 해당하는 항산화력 (L-ascorbic acid equivalent antioxidant capacity, AEAC)으로 나타내었다.

$\mathrm{ABTS}^{+}$radical 소거능은 Lee 등(2015)의 방법을 변형하
여 측정하였다. $7 \mathrm{mM}$ 의 $\mathrm{ABTS}$ 용액과 $2.45 \mathrm{mM}$ 를 potassium persulpate을 혼합한 후 실온인 암실에서 12시간 이상 방치 하였다. ABTS 용액의 농도는 $734 \mathrm{~nm}$ 에서 흡광도가 0.7 $0.8 \mathrm{~nm}$ 가 되도록 희석하였다. 희석된 용액 $180 \mu \mathrm{L}$ 에 시료 $20 \mu \mathrm{L}$ 를 가하여 5 분 방치한 후 흡광도를 측정하였고, 대조 구로 L-ascorbic acid를 이용하였다. 총 항산화력은 Lascorbic acid에 해당하는 항산화력(L-ascorbic acid equivalent antioxidant capacity, AEAC)으로 나타내었다.

\section{통계처리}

실험결과는 SAS 9.4(SAS Institute, Cray, NC, USA) 프로 그램을 이용하여 일원분산분석(One-way ANOVA)을 실시 하였으며, 모든 분석자료는 평균 \pm 표준오차 $(m e a n \pm \mathrm{SD})$ 로 나타내었다. 시료간의 유의적인 차이는 Duncan's Multiple Range Test(DMRT) 방법으로 검정하였다 $(\mathrm{p}<0.05)$.

\section{결과 및 고찰}

\section{건조감량 설정}

지황은 대한민국약전에 건조 감량이 별도로 규정되어 있지 않지만 대표적인 건지황 제조업체들의 건지황을 수 집하여 수분함량을 조사한 결과, 평균적으로 약 $11 \%$ 수분 함량의 건지황이 유통되고 있다(data not shown). 본 연구에 서는 장기저장에 적합한 건조감량을 설정하기 위하여 수분 함량별 $(12,14,16 \%)$ 로 건지황을 제조한 후 3 개월간 품질 변화를 관찰하였다. 저장 시 평균 온도는 $18.60 \pm 3.90^{\circ} \mathrm{C}$ (최저 $10.50^{\circ} \mathrm{C}$, 최고 $27.00^{\circ} \mathrm{C}$ )였고, 평균 습도는 $56.90 \pm 13.90 \% \mathrm{RH}$ (최저 $26.00 \% \mathrm{RH}$, 최고 $86.5 \% \mathrm{RH}$ )로 진행되었다. 그 결과, 모든 조건에서 외관적 특성에서는 차이가 없었으나(Fig. 1), 경도와 부착성 변화에 유의한 차이가 나타났다(Table 2). 경도의 경우, 수분함량 $12 \%$ 건지황에서는 유의한 차이 가 없었지만 $14 \%$ 와 $16 \%$ 건지황에서는 유의하게 감소하였 고, 부착성 또한 $12 \%$ 건지황에서는 유의한 차이가 없었지 만 $14 \%$ 와 $16 \%$ 건지황에서는 유의하게 증가하였다. 즉, 수분함량 $14 \%$ 이상의 건지황에서는 저장 중 품질 변화가 나타난 것으로 생각된다. Lee 등(2008)에 따르면 식품의
(A)

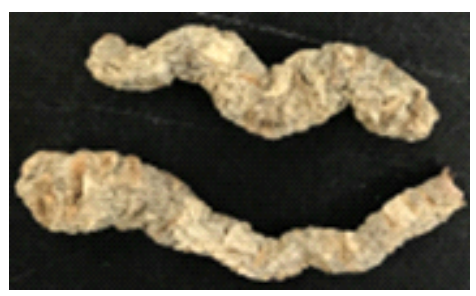

(B)

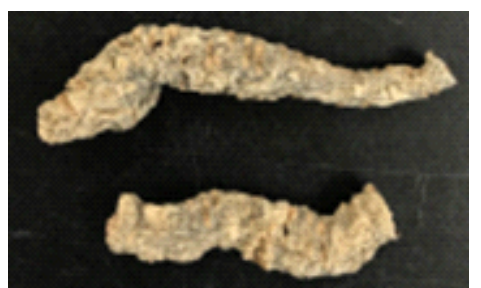

(C)

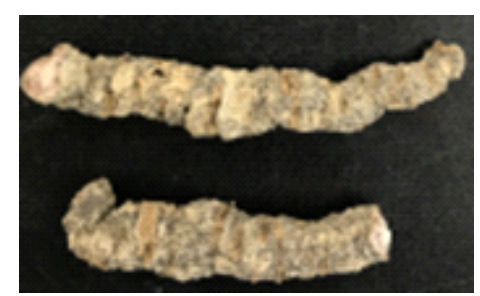

Fig. 1. No change in appearance of dried Rehmanniae glutinosa after 3 months of storage.

(A) $12 \%$ moisture content; (B) 14\% moisture content; (C) $16 \%$ moisture content. 
Table 2. Change of physical characteristics of dried Rehmanniae glutinosa with different moisture content (\%) during storage

\begin{tabular}{cccc}
\hline Moisture content $(\%)$ & 12 & 14 & 16 \\
\hline Hardness $(\mathrm{N})$ & $44.47^{\mathrm{ns})} \rightarrow 44.33^{\mathrm{ns}}$ & $38.10^{\mathrm{a}} \rightarrow 30.63^{\mathrm{b}}$ & $32.23^{\mathrm{a}} \rightarrow 21.53^{\mathrm{b}}$ \\
Adhesiveness $(\mathrm{mJ})$ & $0.11^{\mathrm{ns}} \rightarrow 0.16^{\mathrm{ns}}$ & $0.15^{\mathrm{b}} \rightarrow 0.34^{\mathrm{a}}$ & $0.17^{\mathrm{b}} \rightarrow 0.41^{\mathrm{a}}$ \\
\hline
\end{tabular}

${ }^{1)}$ Not significant.

${ }^{2)}$ Values with different letters are significantly different during storage $(\mathrm{p}<0.05)$.

수분은 조직감에 큰 영향을 주며, 특히 건조식품의 품질은 조직감에 의해 크게 좌우된다고 보고하였다(Jo 등, 1999). 따라서 저장 중 조직감 변화를 고려하였을 때, 외관특성이 유지되고 조직감의 변화가 적었던 수분함량 $12 \%$ 이하의 건조가 장기저장에 적합할 것으로 생각된다.

\section{건조온도에 따른 수분함량 변화 및 건조소요시간}

지황 건조온도에 따른 수분함량 변화는 Fig. 2 와 같이 $40^{\circ} \mathrm{C}, 50^{\circ} \mathrm{C}$ 열풍건조 대비 $70^{\circ} \mathrm{C}$ 이상에서는 수분함량이 급격히 감소하여 24시간 이후로는 수분함량 변화가 나타 나지 않았다. 본 실험에서는 위의 건조감량 설정 실험결과 에 따라 수분함량 $12 \%$ 까지 건조시켰고, 그 결과 온도별 소요시간은 $40^{\circ} \mathrm{C}$ 에서는 288 시간, $50^{\circ} \mathrm{C}$ 는 144 시간, $60^{\circ} \mathrm{C}$ 는 45 시간, $70^{\circ} \mathrm{C}$ 는 22 시간, $80^{\circ} \mathrm{C}$ 는 12 시간으로 나타났다. 즉, $50^{\circ} \mathrm{C}$ 이하에서는 6 일 이상이 소요되는 데에 비해 $60^{\circ} \mathrm{C}$ 이상에서는 2 일 이내로 매우 단축되었다. 건조작업에 있어 건조온도와 시간은 경제적 비용과 노력을 절감시킬 수

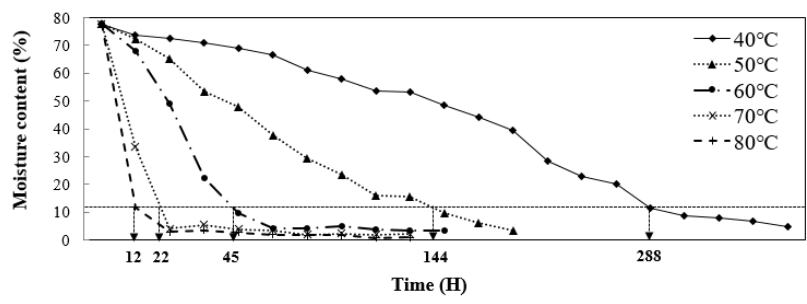

Fig. 2. Change of moisture content (\%) of Rehmanniae glutinosa dried at different temperature.
있는 요인으로, 이를 절감하기 위해서는 온도를 높이는 것이 유리하나, 이는 물리적 - 화학적 특성들을 종합적으 로 고려하여 설정해야 할 것으로 생각된다.

\section{건조온도에 따른 색도와 경도}

건조온도에 따른 물리적 특성으로 색도와 경도를 측정 한 결과, Table 3 과 같다. 색도에서 명도의 경우, 건조온도 가 높아질수록 감소하는 경향을 보였는데, $60^{\circ} \mathrm{C}$ 이상에서 는 유의한 차이가 없었다. 한편, 적색도와 황색도는 온도가 높아질수록 감소하였으나 유의한 차이는 없었다.

경도를 측정한 결과, 상대적으로 저온인 $40^{\circ} \mathrm{C}$ 에서는 경 도가 낮게 나타나다가 $50-60^{\circ} \mathrm{C}$ 에서 가장 높게 나타났다. 반면, $70^{\circ} \mathrm{C}$ 와 $80^{\circ} \mathrm{C}$ 에서는 경도가 다시 감소하여 낮은 값을 보였는데, 이는 고온 건조로 시료의 표면이 빠르게 건조되 면서 압력에 의해 쉽게 부서져, 경도 측정 시 측정이 어렵 거나 낮은 값을 보인 것으로 판단된다. Lee 등(2006)에 따르면 냉풍건조와 천풍건조보다 열풍건조 시 경도가 높 게 나타났는데 이는 고온건조시 표면경화현상이 심해지 며 건조에 의한 수축으로 조직이 치밀해지면서 경도가 높아졌다고 보고하여 본 연구결과와는 달랐다. 이는 고온 건조시 표면의 경화작용이 빠르게 나타나지만 상대적으 로 내부의 조직감이 균일하지 않기 때문으로 생각되며 이러한 조직감은 건조시 품질적인 측면에서 많은 문제점 을 야기하고 있다고 보고되었다(Hur, 2016). 따라서 이러 한 점들을 고려하였을 때 고온건조보다는 $60^{\circ} \mathrm{C}$ 이하의 건조가 유리할 것으로 보인다.

Table 3. Color values and hardness of Rehmanniae glutinosa dried at different temperature

\begin{tabular}{lcccccc}
\hline & & $40^{\circ} \mathrm{C}$ & $50^{\circ} \mathrm{C}$ & $60^{\circ} \mathrm{C}$ & $70^{\circ} \mathrm{C}$ & $80^{\circ} \mathrm{C}$ \\
\hline & $\mathrm{L}$ & $50.18 \pm 0.47^{1 \mathrm{a} 2)}$ & $48.83 \pm 0.86^{\mathrm{a}}$ & $45.09 \pm 0.88^{\mathrm{b}}$ & $44.03 \pm 0.26^{\mathrm{b}}$ & $44.29 \pm 0.37^{\mathrm{b}}$ \\
$\begin{array}{l}\text { Hunter's } \\
\text { value }\end{array}$ & $\mathrm{a}$ & $3.67 \pm 0.80^{\mathrm{a}}$ & $3.34 \pm 0.71^{\mathrm{a}}$ & $2.78 \pm 0.30^{\mathrm{a}}$ & $2.64 \pm 0.59^{\mathrm{a}}$ & $2.87 \pm 0.69^{\mathrm{a}}$ \\
& $\mathrm{b}$ & $14.91 \pm 2.11^{\mathrm{a}}$ & $15.03 \pm 2.33^{\mathrm{a}}$ & $12.96 \pm 0.14^{\mathrm{a}}$ & $12.10 \pm 1.18^{\mathrm{a}}$ & $12.54 \pm 0.61^{\mathrm{a}}$ \\
\hline \multicolumn{2}{l}{ Hardness $(\mathrm{N})$} & $14.47 \pm 1.90^{\mathrm{c}}$ & $44.47 \pm 2.48^{\mathrm{a}}$ & $41.77 \pm 2.78^{\mathrm{a}}$ & $22.43 \pm 2.44^{\mathrm{b}}$ & $18.40 \pm 4.70^{\mathrm{bc}}$ \\
\hline
\end{tabular}

${ }^{1)}$ Values represent mean \pm SD of triplicate determinations.

${ }^{2)}$ Values with different letters are significantly different in a row $(\mathrm{p}<0.05)$. 


\section{건조 온도에 따른 카탈폴 함량}

건조 온도에 따른 카탈폴 함량을 측정한 결과, Fig. 3과 같이 건조 온도가 높아질수록 증가하다가 $80^{\circ} \mathrm{C}$ 이상에서 는 다시 감소하였다. Chang 등(2011)의 연구에서도 카탈폴 이 $80^{\circ} \mathrm{C}$ 이상의 온도에서 감소하여 본 연구결과와 일치하 였다. 그 밖에도 Song 등(2007)에 따르면 숙지황 제조 시 열처리 온도와 시간이 증가할수록 카탈폴 함량이 감소하 였다고 보고하였다. 따라서 카탈폴 함량이 높은 건지황을 이용하기 위해서는 $60-70^{\circ} \mathrm{C}$ 범위의 수확 후 건조 등 가공 과정을 거치는 것이 유리한 것으로 판단된다.

\section{열처리에 따른 카탈폴 함량}

카탈폴은 지황의 주요 유효성분으로, 특히 최근 많은 현대인들이 겪는 고혈당, 당뇨 등에 관해 혈당강하 효과가 있는 것으로 알려져(In 등, 2015) 건강기능성식품이나 치 료제 개발 등 산업적 활용에 가능성이 높은 성분이다. 하지 만 지황의 경우, 생지황으로 이용하기도 하지만 주로 건조 혹은 증숙과정을 통하여 사용되는 경우가 많기 때문에, 이 성분을 활용하기 위해 적절한 열처리 과정을 거치는 것이 중요하다. 따라서 본 연구에서는 카탈폴 성분의 열에 대한 안정성을 확인해보기 위하여 catalpol(Sigma, Cat. No. 50839) 표준액만을 열처리하여 함량 변화를 관찰하였다.

그 결과, 지황을 열풍건조한 결과 (Fig. 3)와 달리, 카탈폴 자체를 열처리하였을 때는 Table 4와 같이 열처리 후 함량에

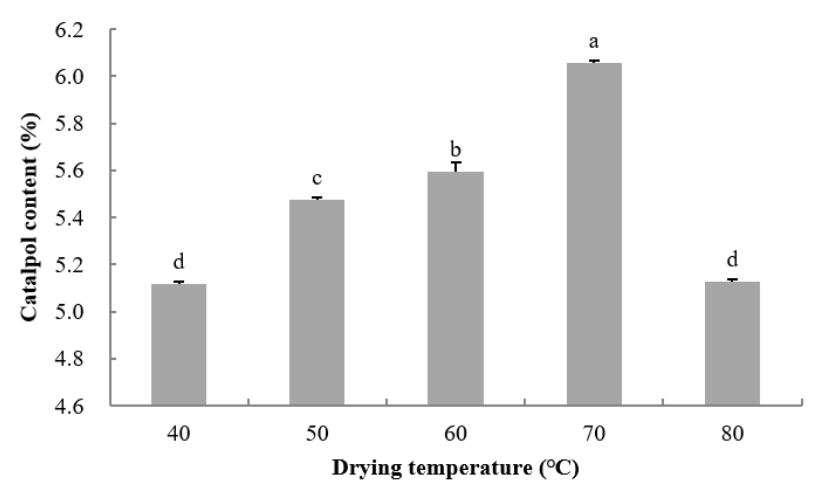

Fig. 3. Catalpol content (\%) of Rehmanniae glutinosa dried at different temperature.

Values represent mean $\pm \mathrm{SD}$ of triplicate determinations. Values with different letters on the bar are significantly different $(p<0.05)$.
유의한 차이가 없었다. 따라서 카탈폴 성분 자체가 온도에 따라 민감하게 변하는 것이 아니라, 지황 내부에 카탈폴 분해에 관여하는 다른 요인이 있기 때문으로 추측된다. 이 와 관련하여 Schopohl 등(2014)에 따르면 카탈폴 또는 아큐 빈과 같은 이리도이드 물질은 $\beta$-glucosidases와 같은 분해효 소에 의해 분해될 수 있다고 보고하였으며, 이러한 변화는 수확 후 건조, 가공, 저장, 추출, 그리고 신체 내 대사 작용에 의해서도 일어날 수 있고, 특히 중성에서는 안정하나, 산과 염기에는 매우 민감하여 분해될 수 있다고 알려져 있다(Wei 와 Wen, 2014). 즉, 본 연구에서도 건조 온도에 따라 지황 내부의 효소 활성과 $\mathrm{pH}$ 변화가 발생하여 건조 시 지황의 카탈폴 함량에 차이가 나타난 것으로 생각된다.

\section{건조 온도에 따른 총 폴리페놀 및 총 플라보노이드 함량}

건조 온도에 따른 항산화 성분을 측정한 결과, Fig. 4와 같이 건조온도에 따라 유의한 차이를 보였다. 총 폴리페놀 과 총 플라보노이드 모두 건조온도가 낮은 범위 $\left(40-50^{\circ} \mathrm{C}\right)$ 보다는 높은 범위 $\left(70-80^{\circ} \mathrm{C}\right)$ 에서 항산화 성분 함량이 더 높았다. 총 폴리페놀함량 $70^{\circ} \mathrm{C}$ 까지 증가하다가 감소하는 경향을 보였으며, 총 플라보노이드 역시 $70^{\circ} \mathrm{C}$ 에서 가장 높았고, 그 후 감소하였다. 일반적으로 총 페놀성 화합물은 열처리에 의해 결합형에서 유리형으로 전환되어 용출이 용이해지거나, 고분자 페놀화합물이 저분자 페놀화합물 로 분해되기 때문에 열처리 온도가 올라갈수록 플라보노 이드나 폴리페놀과 같은 항산화 성분의 함량이 증가하는 것으로 보고된 바 있는데(Hwang 등, 2006; Lee 등, 2009; Hwang 등, 2011), 이는 본 연구결과와도 일치하였다. 다만 본 연구결과에서 $70^{\circ} \mathrm{C}$ 이후 두 성분 모두 함량이 감소하였 는데, 이는 $80^{\circ} \mathrm{C}$ 에서는 건조소요시간이 12 시간으로, 건조 소요시간이 22 시간이었던 $70^{\circ} \mathrm{C}$ 에 비해 상대적으로 열처 리 시간이 짧았기 때문에 용출과 분해가 충분히 일어나지 못한 것으로 생각된다. 따라서 항산화 성분이 높은 건지황 을 생산하기 위해서는 낮은 온도보다는 $60^{\circ} \mathrm{C}$ 이상 온도에 서의 건조작업이 유리할 것으로 판단된다.

\section{건조 온도에 따른 항산화 활성}

건조 온도에 따른 항산화 활성을 측정한 결과, Fig. 5 와 같이 건조온도가 증가함에 따라 전체적으로 증가하다가

Table 4. Change of catalpol contents (\%) of Rehmanniae glutinosa with heating treatments

\begin{tabular}{lllll}
\hline & $100^{\circ} \mathrm{C} 0 \mathrm{~h}$ & $100^{\circ} \mathrm{C} 4 \mathrm{~h}$ & $100^{\circ} \mathrm{C} 8 \mathrm{~h}$ & $100^{\circ} \mathrm{C} 12 \mathrm{~h}$ \\
\hline Catalpol (\%) & $6.98 \pm 0.18^{1 \text { )ns2 }}$ & $7.07 \pm 0.79^{\text {ns }}$ & $7.07 \pm 0.24^{\text {ns }}$ & $6.95 \pm 0.17^{\text {ns }}$ \\
\hline
\end{tabular}

${ }^{1)}$ Values represent mean \pm SD of triplicate determinations.

${ }^{2)}$ Values with different letters are significantly different $(\mathrm{p}<0.05)$. 

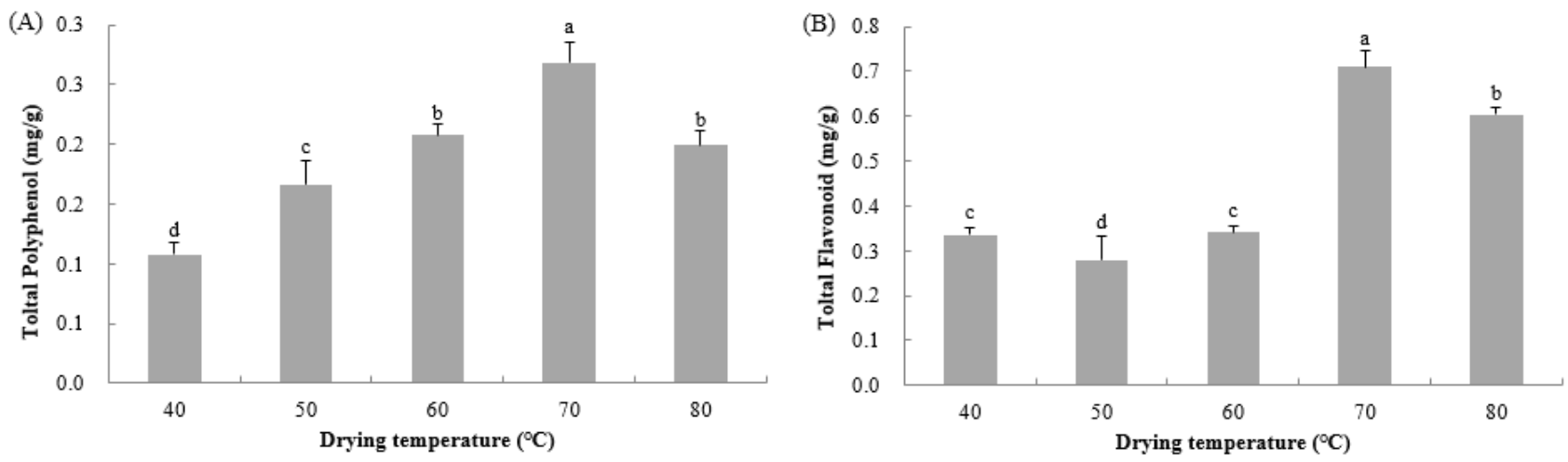

Fig. 4. Total polyphenol (A) and flavonoid (B) contents of Rehmanniae glutinosa dried at different temperatures.

Values represent mean $\pm \mathrm{SD}$ of triplicate determinations. Values with different letters on the bar are significantly different $(\mathrm{p}<0.05$ ).
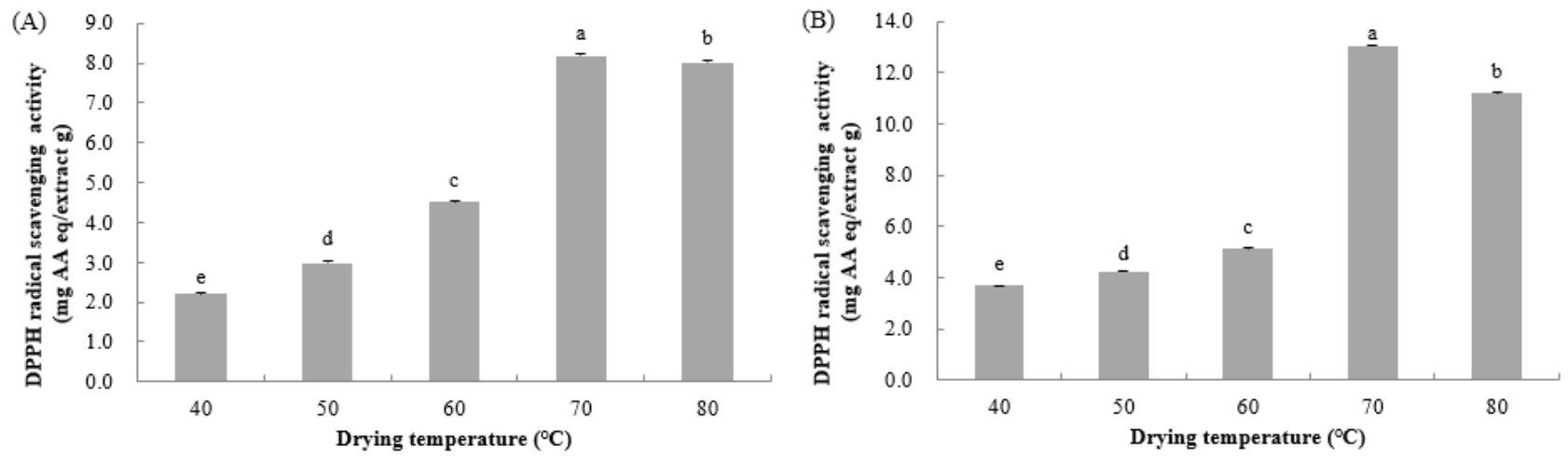

Fig. 5. DPPH radical scavenging activity (A) and ABTS radical scavenging activity (B) Antioxidant activities of Rehmanniae glutinosa dried at different temperatures.

Values represent mean $\pm \mathrm{SD}$ of triplicate determinations. Values with different letters on the bar are significantly different ( $<<0.05$ ).

$70^{\circ} \mathrm{C}$ 이후로는 감소하여 총 폴리페놀과 플라보노이드 경 향과 일치하였다. 총 폴리페놀과 플라보노이드는 항산화 활성에 관여하는 대표적인 물질로, Seo 등(2008)의 연구에 서도 폴리페놀함량과 총 항산화력이 높은 상관관계 $\left(\mathrm{R}^{2}=\right.$ 0.9921)를 보였다고 보고된 바 있다. 따라서 항산화 성분과 마찬가지로 높은 항산화 활성을 갖는 건지황을 제조하고 자 한다면, $40-50^{\circ} \mathrm{C}$ 와 같이 낮은 온도보다는 $70-80^{\circ} \mathrm{C}$ 의 높은 온도에서 건조하는 것이 항산화 측면에서 우수한 특성을 가질 것으로 판단된다. 다만 생약의 고유 특성상 대한민국약전의 통칙에서 보통 건조를 $60^{\circ} \mathrm{C}$ 이하로 규정 한다는 점과 이화학적 특성, 건조시간 등을 종합적으로 고려하였을 때 열풍건조 시 $60^{\circ} \mathrm{C}$ 에서의 건조가 가장 적합 할 것으로 판단된다.

\section{요 약}

본 연구에서는 항당뇨, 면역증진 등 다양한 생리활성을
갖는 지황의 산업적 활용도를 높이고자 장기저장에 적합 한 건조감량을 설정하고, 건조온도별로 건지황을 제조한 후 품질 특성 및 항산화 활성을 조사하였다. 건조 시 수분 함량은 $12 \%$ 이하로 건조하는 것이 외관특성과 조직감 등 의 품질변화가 가장 적었다. 건지황의 색도는 건조온도가 증가함에 따라 명도가 감소하였는데 $60^{\circ} \mathrm{C}$ 이후로는 유의 한 차이가 없었고 경도는 $50-60^{\circ} \mathrm{C}$ 에서 높게 나타났다. 한편 카탈폴 함량과 항산화 성분, 항산화 활성은 온도가 증가할수록 높아졌으며 $70^{\circ} \mathrm{C}$ 에서 가장 높았다. 따라서 물 리적인 측면에서는 $50-60^{\circ} \mathrm{C}$, 카탈폴 함량 및 항산화 성분 과 활성을 고려하면 $60-70^{\circ} \mathrm{C}$ 가 가장 효과적이었으므로 최종적으로 $60^{\circ} \mathrm{C}$ 에서의 열풍건조가 가장 적합할 것으로 사료된다.

\section{감사의 글}

본 논문은 농촌진흥청 연구사업(과제번호: PJ010267401) 
의 지원에 의해 이루어진 결과로 이에 감사드립니다.

\section{Conflict of interests}

The authors declare no potential conflict of interest.

\section{ORCID}

Yae Jin Kim https://orcid.org/0000-0002-7776-7117

Sin Hee Han https://orcid.org/0000-0001-7360-2473

\section{References}

AOAC. Official Methods of Analysis. 16th ed, Association of Official Analytical Chemists, Washington DC, USA, p 69-74 (1995)

Chang JP, Kil GJ, Lee GH, Ji YS, Kim BR, Kang KH, Kim MR, Song MR, Park JY, Doh ES. Change of inorganic component, reducing sugar, catalpol and benzo[a]pyrene contents of Rehmannia glutinosa Libosch. var. purpurea Makino by drying methods. Korean J Medicinal Crop Sci, 19, 501-507 (2011)

Chang IM. Liver-protective activities of aucubin derived from traditional oriental medicine. Res Commun Mol Pathol Pharmacol, 102, 189-204 (1998)

Chao JCJ, Chiang SW, Wang CC, Tsai YH, Wu MS. Hot water-extracted Lycium barbarum and Rehmannia glutinosa inhibit proliferation and induce apoptosis of hepatocellular carcinoma cells. World J Gastroenterol, 12, 4478-4484 (2006)

Folin O, Denis W. On phosphotungstic-phosphomolybdic compounds as color reagents. J Biol Chem, 12, 239-249 (1912)

Han SH, Jang JK, Ma KH, Kim YJ, Kim SM, Lee HJ, Hong $\mathrm{CO}$. Selection of superior resources through analysis of growth characteristics and physiological activity of Schisandra chinensis collection. Korean J Medicinal Crop Sci, 27, 9-16 (2019)

Hur SS. Effects of the low temperature vacuum drying process on drying curve and physico-chemical properties of astringent persimmons. J of Korean Oil Chemists' Soc, 33, 58-66 (2016)

Hwang CR, Oh SH, Kim HY, Lee SH, Hwang IG, Shin YS, Lee JS, Jeong HS. Chemical composition and antioxidant activity of Deoduk (Codonopsis lanceolata) and Doragi (Platycodon grandiflorum) according to temperature. J
Korean Soc Food Sci Nutr, 40, 798-803 (2011)

Hwang IG, Woo KS, Kim TM, Kim DJ, Yang MH, Jeong HS. Change of physicochemical characteristics of Korean pear (Pyrus pyrifolia Nakai) juice with heat treatment conditions. Korean J Food Sci Technol, 38, 342-347 (2006)

In JD, Im DS, Moon SH, Kim WI. Characteristic effects of Dangnyo-hwan for diabetes control studied using LCMS/MS and ICP. J Int Korean Med, 36, 217-227 (2015) Jiang B, Shen RF, Bi J, Tian XS, Hinchliffe T, Xia Y. Catalpol: A potential therapeutic for neurodegenerative diseases. Curr Med Chem, 22, 1278-1291 (2015)

Jo JH, Oh SW, Lee NH, Do JR. Processing conditions of expanded anchovy snack and monolayer moisture content of the products. Korean J Food Sci Technol, 31, 380-384 (1999)

Ministry of Food and Drug Safety. The Korean Pharmacopoeia, 11th ed, The KFDA Notification, Osong, Korea, p 99 (2014)

Lee HJ, Oh SH, Choi KH. Studies on the general composition, rheometric and microbiological change of pacific saury, Coloabis saira kwamaegi on the storage temperatures and durations. J Korean Soc Food Sci Nutr, 21, 165-175 (2008)

Lee HJ, Lee SW, Park CG, Ahn YS, Kim JS, Bang MS, Oh CH, Kim CT. Effects of white Habiscus syriacus L. flower extracts on antioxidant activity and bone resorption inhibition. Korean J Medicinal Crop Sci, 25, 190-197 (2015)

Lee SH, Hwang IG, Lee YR, Joung EM, Jeong HS, Lee HB. Physicochemical characteristics and antioxidant activity of heated radish (Raphanus sativus L.) extracts. J Korean Soc Food Sci Nutr, 38, 490-495 (2009)

Lee WY, Cha WS, Oh SL, Cho YJ, Lee HY, Lee BS, Park JS, Park JH. Quality characteristics of dried radish (Raphanus sativus) by drying methods. Korean J Food Preserv, 13, 37-42 (2006)

Li DQ, Li Y, Liu Y, Bao YM, Hu B, An LJ. Catalpol prevents the loss of CA1 hippocampal neurons and reduces working errors in gerbils after ischemia-reperfusion injury. Toxicon, 46, 845-851 (2005)

Liu FJ, Zhao XN, Nie W, Tang JF, Ru XB, Gu GM. Improvements of Rehmannia glutinosa oligosaccharides on immune functions in mice. CPB, 14, 90 (1998)

Park NK, Kim SL, Hur HS, Park CH. Development of R. Radix preparata with new Variety "Jiwhang 1". Korean 
J Intl Agri, 14, 34-39 (2002)

Oh KO, Kim SW, Kim JY, Ko SY, Kim HM, Baek JH, Ryoo

HM, Kim JK. Effect of Rehmannia glutinosa Libosch extracts on bone metabolism. Clin Chim Acta, 334, 185-195 (2003)

Reina E, Al-Shibani N, Allam E, Gregson KS, Kowolik M, Windsor LJ. The effects of Plantago major on the activation of the neutrophil respiratory burst. J Tradit Complement Med, 3, 268-272 (2013)

Schopohl P, Grueneberg P, Melzig MF. The influence of the iridoids aucubin, catalpol and harpagosid as well as their metabolites on innate immune function. Planta Med, 80, 16, 34 (2014)

Seo SJ, Choi YM, Lee SM, Kong SH, Lee JS. Antioxidant activities and antioxidant compounds of some specialty rices. J Korean Soc Food Sci Nutr, 37, 129-135 (2008) Song DS, Woo KS, Seong NS, Kim KY, Jeong HS, Lee $\mathrm{HB}$. Changes in quality of Rehmanniae radix preparata with heating conditions. J Korean Soc Food Sci Nutr, 36, 773-778 (2007)

Wei GD, Wen XS. Characteristics and kinetics of catalpol degradation and the effect of its degradation products on free radical scavenging. Pharmacogn Mag, 10, 122-129 (2014)

Zhao M, Tao J, Qian D, Liu P, Shang E, Jiang S, Guo J, Su S, Duan J, Du L. Simultaneous determination of loganin, morroniside, catalpol and acteoside in normal and chronic kidney disease rat plasma by UPLC-MS for investigating the pharmacokinetics of Rehmannia glutinosa and Cornus officinalis Sieb drug pair extract. J Chromatogr B, 10091010, 122-129 (2016)

Zhou J, Xu G, Ma S, Li F, Yuan M, Xu H, Huang K. Catalpol ameliorates high-fat diet-induced insulin resistance and adipose tissue inflammation by suppressing the JNK and NF-kB pathways. Biochem Biophys Res Commun, 467, 853-858 (2015) 